\title{
Protein Flotation Assay to Isolate Lipids Rafts from Soft Tissue or Cells
}

Catherine Lemaire-Vieille*, Jean Gagnon and Jean-Yves Cesbron

LAPM, UJF-CNRS UMR 5163, Grenoble, France

*For correspondence: catherine.lemaire@ujf-grenoble.fr

[Abstract] The arrangement in eukaryotic cell membranes of liquid-ordered states surrounded by liquid-disordered phases allows for the existence of organized membrane microdomains called rafts. Rafts play a crucial role in signal-transduction events, in lipid transport and in various internalization processes, and for all these reasons need to be purified for further characterization.

\section{Material and Reagents}

1. Optiprep ${ }^{\circledR}$ (Optiprep ${ }^{\circledR}$ is a $60 \%$ solution of iodixanol in water, density $=1.32 \mathrm{~g} / \mathrm{ml}$ ) (SigmaAldrich, catalog number: 079K1726)

2. Sodium chloride $(\mathrm{NaCl})$

3. Tris hydrochloride (Tris-HCl)

4. Ethylenediaminetetraacetic acid (EDTA) (Sigma-Aldrich, catalog number: ED255)

5. Triton X-100 (Sigma-Aldrich, catalog number: T-8532)

6. Methanol/chloroform

7. Lysis buffer (see Recipes)

8. Gradient buffer (see Recipes)

\section{Equipment}

1. Pellet pestles (Sigma-Aldrich, catalog number: Z359963-1EA)

2. Sorvall $\circledast$ WX90 ultracentrifuge (Thermo Fisher Scientific, catalog number: 46901)

3. Sorvall@ TH-641 swinging bucket rotor (Thermo Fisher Scientific, catalog number: 54295 )

4. Ultracentrifuge tubes: Beckman Coulter ${ }^{\circledR}$ open-top Ultra-ClearTM tubes (dimension: $14 \mathrm{x}$ $89 \mathrm{~mm}$, nominal volume: $12 \mathrm{ml}$ ) (Beckman Coulter ${ }^{\circledR}$, catalog number: 344059)

5. $1 \mathrm{ml}$ pipette

6. Western Blotting apparatus

\section{Procedure}

1. Extract appropriate tissue homogenates for $2 \mathrm{~h}$ on ice in cold lysis buffer (total protein: 1 
$\mathrm{mg}$ in $1 \mathrm{ml}$ ). Soft tissue (or cell pellet) is hand-disrupted in microcentrifuge tubes with a pestle. Pestle end mates well with $1.5 \mathrm{ml}$ microtubes and shaft allows gentle manual back-and-forth rotation.

2. Assemble the gradient

a. Prepare all solutions extemporaneously and kept on ice.

i. $\quad$ Prepare a $30 \%$ Optiprep ${ }^{\circledR}$ solution in gradient buffer (1 volume of Optiprep ${ }^{\circledR}$ in 1 volume gradient buffer).

ii. $\quad$ Prepare a $5 \%$ Optiprep ${ }^{\circledR}$ solution in gradient buffer (1 volume of Optiprep ${ }^{\circledR}$ in 11 volumes gradient buffer).

iii. Mix the extracts ( $1 \mathrm{ml}$ in lysis buffer) with two volumes $(2 \mathrm{ml})$ of cold $60 \%$ Optiprep $^{\circledR}$ to reach a final concentration of $40 \%$.

b. Load the extracts ( $3 \mathrm{ml}$ in $40 \%$ Optiprep $^{\circledR}$ ) at the bottom of the ultracentrifuge tubes, add very slowly $6 \mathrm{ml}$ of $30 \%$ Optiprep ${ }^{\circledR}$ onto the lysate and then add very slowly 2.5 $\mathrm{ml}$ of $5 \%$ Optiprep ${ }^{\circledR}$ onto the $30 \%$ Optiprep $^{\circledR}$.

Note: It is important to avoid mixing of the interfaces. A good way is to let the pipet tip barely touch the surface and slowly overlay the solution while the tip is brought up along the side of the tube.

3. Make sure the tubes (including buckets and caps) are equilibrated. Put the tubes in the buckets of the Sorvall $\mathrm{TH}-641$ rotor pre-cooled at $4{ }^{\circ} \mathrm{C}$, and screw the caps on the buckets. Spin at $100,000 \times g$ for $24 \mathrm{~h}$ at $4{ }^{\circ} \mathrm{C}$.

4. Analyze the gradient

a. Collect the fractions $(1 \mathrm{ml})$ by gentle and slow aspiration from the meniscus at the top of the tube with an automatic $1 \mathrm{ml}$ pipette, making sure that the tip of the pipette follows the lowering meniscus. Rafts should be present within the low-density fractions 2 to 4 which is the interface between the 30 and the $5 \%$ density.

b. The equivalent of $300 \mu \mathrm{l}$ is precipitated by the methanol/chloroform method and processed for Western blotting. The fractions can be stored at $-80{ }^{\circ} \mathrm{C}$ for up to 6 months. The protocol used for precipitation is that described in Aboulaich (2011). Always check on the distribution of raft markers in the gradient to confirm that the centrifugation has achieved a satisfactory resolution and recovery of rafts, Flotillin-1 which has been shown to be enriched in lipid rafts is the most widely used. For brain tissue, we have used prion protein which is also present in lipid rafts.

\section{$\underline{\text { Recipes }}$}

1. Lysis buffer

$150 \mathrm{mM} \mathrm{NaCl}$ 


\section{bĭo-protocol}

25 mM Tris- $\mathrm{HCl}(\mathrm{pH} 7.4)$

5 mM EDTA

1\% Triton X-100

Filter sterilize and keep at $4{ }^{\circ} \mathrm{C}$.

2. Gradient buffer

$150 \mathrm{mM} \mathrm{NaCl}$

$25 \mathrm{mM}$ Tris- $\mathrm{HCl}(\mathrm{pH} 7.4)$

5 mM EDTA

Filter sterilize and keep at $4{ }^{\circ} \mathrm{C}$.

\section{Acknowledgments}

This protocol is adapted from Lemaire-Vieille et al. (2013).

\section{References}

1. Aboulaich, N. (2011). Protein precipitation from detergent-containing samples. Bioprotocol 1(5): e40.

2. Lemaire-Vieille, C., Bailly, Y., Erlich, P., Loeuillet, C., Brocard, J., Haeberle, A. M., Bombarde, G., Rak, C., Demais, V., Dumestre-Perard, C., Gagnon, J. and Cesbron, J. Y. (2013). Ataxia with cerebellar lesions in mice expressing chimeric PrP-Dpl protein. $J$ Neurosci 33(4): 1391-1399.

3. Persaud-Sawin, D. A., Lightcap, S. and Harry, G. J. (2009). Isolation of rafts from mouse brain tissue by a detergent-free method. J Lipid Res 50(4): 759-767. 